\title{
Steam technologies in Western education: new approaches to literary text study
}

\section{Steam technologies na educação ocidental: novas abordagens para o estudo de textos literários}

\section{Steam technologies en la educación occidental: nuevos enfoques para el estudio de textos literarios}

\author{
Elena Getmanskaya ${ }^{1}$ iD \\ ${ }^{1}$ Moscow Pedagogical State University, Moscow, Russia. \\ Corresponding author: \\ Elena Getmanskaya \\ Email: egetmanskaya@internet.ru \\ How to cite: Getmanskaya, E. (2021). Steam technologies in Western education: new approaches to literary text study. \\ Revista Tempos e Espaços em Educação, 14(33), e16561. http://dx.doi.org/10.20952/revtee.v14i33.16561
}

\begin{abstract}
The article deals with the Western concept of STEAM education which is based on a certain "polysubject" which includes Science (S), Technology (T), Engineering (E), Arts (A), and Mathematics (M). The practice of this educational approach is focused on the following idea: a student who is familiar with the artistic principles of life (literature, art, music, design) will achieve more in Mathematics, Invention and Natural Sciences. STEAM eliminates the continuous dispute between "physicists" and "lyricists" because within its framework, a lyricist can be talented in engineering (invention) and a physicist can be talented in aesthetic, artistic manifestations such as design. The analysis of Western STEAM models of studying literary text poses questions about the trajectories of modern literary education which is transforming in a sense. An educational STEAM product in the analysis of a literary text is oriented primarily towards the designer solution as the manifestation of the students' creative potential. Ultimately, Western studies present the STEAM approach as a humancentric (not subject-centric) model: the approach prioritizes the student's personality and individuality. STEAM education is a new integrative educational system that integrates the scientific and the imaginative, the documental and the aesthetic, the artistic and the rational principles.

Keywords: STEAM technologies. Literary education. Multidisciplinary. Design. Visual arts. Physicists and lyricists.

\section{RESUMO}

$O$ artigo trata do conceito ocidental de educação STEAM que se baseia em uma certa "polidisciplina" que inclui Ciências (S), Tecnologia (T), Engenharia (E), Artes (A) e Matemática (M). A
\end{abstract}


prática desta abordagem educacional está focada na seguinte ideia: um aluno que está familiarizado com os princípios artísticos da vida (literatura, arte, música, design) terá mais resultados em Matemática, Invenções e Ciências Naturais. O STEAM elimina a disputa contínua entre "físicos" e "letristas" porque, dentro de sua estrutura, um letrista pode ser talentoso em engenharia (invenção) e um físico pode ser talentoso em manifestações estéticas e artísticas como o design. A análise dos modelos STEAM ocidentais de estudar textos literários levanta questões sobre as trajetórias da educação literária moderna, que está se transformando em certo sentido. Um produto educacional STEAM na análise de um texto literário é orientado principalmente para a solução do designer como a manifestação do potencial criativo dos alunos. Em última análise, os estudos ocidentais apresentam a abordagem STEAM como um modelo centrado no ser humano (não centrado no assunto): a abordagem prioriza a personalidade e a individualidade do aluno. A educação STEAM é um novo sistema educacional integrador que integra o científico e o imaginativo, o documental e o estético, o artístico e os princípios racionais.

Palavras-chave: Tecnologias STEAM. Educação literária. Multidisciplinar. Projeto. Artes visuais. Físicos e letristas.

\section{RESUMEN}

El artículo trata sobre el concepto occidental de educación STEAM que se basa en un cierto "polisujeto" que incluye Ciencias (S), Tecnología (T), Ingeniería (E), Artes (A) y Matemáticas (M). La práctica de este enfoque educativo se centra en la siguiente idea: un estudiante que esté familiarizado con los principios artísticos de la vida (literatura, arte, música, diseño) logrará más en Matemáticas, Invención y Ciencias Naturales. STEAM elimina la disputa continua entre "físicos" y "letristas" porque dentro de su marco, un letrista puede tener talento en ingeniería (invención) y un físico puede tener talento en manifestaciones estéticas y artísticas como el diseño. El análisis de los modelos STEAM occidentales de estudiar el texto literario plantea interrogantes sobre las trayectorias de la educación literaria moderna que, en cierto sentido, se están transformando. Un producto STEAM educativo en el análisis de un texto literario está orientado principalmente hacia la solución del diseñador como manifestación del potencial creativo de los estudiantes. En última instancia, los estudios occidentales presentan el enfoque STEAM como un modelo humanéntrico (no centrado en la asignatura): el enfoque prioriza la personalidad y la individualidad del estudiante. La educación STEAM es un nuevo sistema educativo integrador que integra los principios científico e imaginativo, documental y estético, artístico y racional.

Palabras clave: Tecnologías STEAM. Educación literaria. Multidisciplinario. Diseño. Artes visuales. Físicos y letristas.

\section{INTRODUCTION}

The development of the STEAM approach is one of the main trends in global education. The approach integrates Science (S), Technology $(T)$, Engineering (E), Arts (A) and Mathematics (M). The specialists of the future require comprehensive training in the exact sciences, biology, engineering, design - and this future is being forged today. STEAM education is introduced in Western schools from an early age. The most important theoretical idea of this approach is the statement - a student who is familiar with the artistic principles of life (literature, art, music, design) will achieve more in Mathematics, Invention and Natural Sciences.

The STEAM curriculum for Literature is also based on interdisciplinary and applied approaches. The purpose of the lesson on the analysis of a literary text, as a rule, is associated with students creating a material object (model), in which their knowledge in all the above disciplines is integrated. With this approach, Design becomes the main tool for interpreting a literary text. With the help of design, in the lesson, not only design tasks are solved - Design here acts as one of the basic forms of modern visual art. 
The main question that we faced is whether it is possible to implement such technologies at school without losses for the studied literary work. The analysis of Western models leads to the conclusion that the significance of Literature as an independent subject under the STEAM approach is changing - part of its autonomy is delegated to other disciplines. At the same time, a new, unexpected configuration of subjects forms in the lesson: Literature is now integrated with Biology, Design, and Mathematics. Thus, the interdisciplinary basis of STEAM brings teaching Literature to a new interdisciplinary level and at the same time raises questions about the degree of presence of the literary text in this approach, the laws of its creation and the depth of its interpretation by schoolchildren.

\title{
METHODS
}

The STEAM approach in modern Western education often leads to paradoxical or, at least, unorthodox practical solutions. This is evidenced, for example, by the article "Literary Digest: Cannibal Poetry and Biology" (2017) in the STEAM Journal by researchers from the University of Chicago. The authors describe the experience of including a lecture on human biology in the course of world literature (Anzaldo et al., 2017). The main product of the lesson is students writing poetry that could connect the physiological process of digestion with the "cannibal poetry" studied in the course of world literature, where cannibalism is viewed as an instrument of political and economic demonization on the part of the conquering powers. The lesson plan was developed by two teachers - a philologist and a biologist. Students were offered a thirty-minute guest lecture with a presentation "Human Digestion" that brought together extremely distant subject areas. The lecture material was supposed to help students create their own poetic work. Ony should immediately note that the article emphasizes the students' positive reaction to both the guest lecture on digestion and the assignment on versification. To receive an " $A$ " grade for their literary work, students had to:

- relate the social phenomenon of cannibalism to the essence of the human digestive process;

- demonstrate a clear understanding of the concepts/process in the digestion lecture;

- create a poem (in at least ten syllables), including a clearly developed pattern of the number of syllables per line, using a metaphor or a simile (Anzaldo et al., 2017).

To assess the success of the teachers' ideas, we present the text of one of the student poems included by the Chicago researchers:

\author{
Digestion Poem \\ Pink, empty, and warm, \\ Dead, still delectable, \\ The white ground iced, \\ Splattered red with life's blood, \\ Which slithers down, \\ That hollow tube of flesh, \\ Esophagus, \\ Coating the pitted walls, \\ of my stomach, \\ Oven of my body, \\ Dissolved and churned, \\ Sent through the coiled snake, \\ Lined with villi, \\ Soft as supple velvet, \\ To drain the life, \\ From your flesh to mine,
}


Become a part,

Of this lone cannibal

(Anzaldo et al., 2017).

Naturally, for a detailed assessment of this text, one would need a thorough culturological and poetical analysis: to what extent the physiological nature of the text reflects the degree of its artistry and how this artistic experiment contributes to the understanding of the social phenomenon of cannibalism. What role does physiology play? Is it a trigger for interest in poetry? Can the description of physiological processes be such an impulse?

Evidence-based research into the efficiency of STEAM practices in the study of the literary text is, rather, a perspective. The task is to describe STEAM models that capture the analysis of literary text into their orbit. Let us turn to elementary school: the American website "Institute for Arts Integration and STEAM" (n.d.) contains STEAM curricula and lesson plans for schools. A lesson for the second grade is based on the book Mufaro's Beautiful Daughters: An African Tale by John Steptoe (1987). The tale by J. Steptoe is found in many American literary curricula and is, in a way, a variant of the Cinderella story. The plot of the tale is simple and instructive: the two daughters of a villager Mufaro, Nyasha and Manyara, show themselves in different ways during the king's search for a future wife. One is aggressive and selfish, the other is kind and helpful. The king secretly disguises himself to discover the true nature of both girls without being recognized. In the end, the king chooses the kind and generous Nyasha, and Manyara becomes her servant (Steptoe, 1987). The subjects that, according to scholars, the creators of the site, can be integrated when performing tasks based on the fairy tale within the framework of STEAM technologies:

- traditional visual art - a drawing of a chosen scene from the fairy tale;

- the latest visual techniques (interior, graphic design, architecture) - 3D design of Mufaro's house;

- object design - making a mask of the African tribe;

- elements of geography - a map of Nyasha's path to the king's palace;

- $\quad$ storytelling - a comic based on the fairy tale;

- music-drumming to the rhythm of African beats;

- theater - staging a fairy tale fragment in a school theater;

- social studies and ethics - a discussion about the rich and the poor, about the good and the bad.

As the lesson brochure emphasizes, "Exploring tales like this one from Africa is a terrific way for students to learn about legends and symbols. This story is so rich in detail from the illustrations that it could easily be transformed into a way to study mask-making, musical drumming, or even as a reader's theater piece" (Steptoe, 1987, p. 11).

As for STEAM lessons in middle school, let us turn to the English literature program for high school in the British school and see how STEAM technologies "shine through" in modern UK state programs (Department for Education, 2014). There is an advanced English literature program designed for the last two years of school; exam results in this discipline are required for admission to the university. The objectives of the program: stimulating students' interest in literary studies and literature in general; achieve reader enjoyment as a result of reading as students:

$\checkmark$ read widely and independently both set texts and others that they have selected for themselves;

$\checkmark$ engage critically and creatively with a substantial body of texts and ways of responding to them;

$\checkmark$ develop and effectively apply their knowledge of literary analysis and evaluation;

$\checkmark$ explore the contexts of the texts they are reading and others' interpretations of them (Department for Education, 2014). 
One should note that the STEAM technologies are not described in the explanatory note, but there is "creative engagement with a text" and "exploring the contexts and interpretations of texts", which, of course, allows the use of a broad interdisciplinary approach when studying a literary text. Let us consider in this interdisciplinary "plane" a lesson for grades 8-12 "A literary character designs his home" (STEM ELA Activity, n.d.). The "products" of this lesson should be:

$\checkmark$ an explanatory paper about the literary character's home with quotations from the text;

$\checkmark$ a sketch of the interior (for example, a floor layout);

$\checkmark$ a sketch of the house exterior.

Before starting the lesson, the teacher refers students to websites (including the Reuters site), which showcase the most unusual houses in the world (Willett-Wei, 2013; Temple, 2012; MelisBuzzFeed, 2011). Students, conveying their impressions of the dwellings, answer the questions: which house seemed to them the most interesting and why; in which one the students would prefer to live; which is considered the most attractive; what structure looks the most convenient for everyday life? Afterward, the teacher offers a list of questions and tasks under the topic "Your character as an architect" that will help students build a text about the character and their intended home:

Choose a fictional character from the work you are currently studying. Think about their most characteristic feature.

What three elements would your character use when designing a home based on what is important to them?

What architectural style do you think the character would use when designing a house and why?

Who would your character want to live in this house?

What will make your character's home unique, suitable only for them?

Include a quotation from the text to show the specific connection between the house and the character.

Describe an office, living room, etc. that your character would create for themselves. Explain why this room will fit their disposition.

When working on the house exterior, the teacher recommends making a sketch without worrying about perfect lines, taking into account only the key elements and thinking about the image of the character as a possible architect of the house. It is proposed to create a floor plan on an approximate scale; key details can be a spiral staircase, dressing room, kitchen, etc.

After students have sketched the interior and exterior of the house, the teacher asks them to choose two interior and exterior design elements and explain in their explanatory paper (with quotations from the text) how their choice reflects their understanding of the character's nature. In the final assessment sheet, with flawless execution of tasks, as a result, a hundred-point mark is given, which consists of 25 maximum points for a sketch of the interior, the same number of points for a sketch of the house exterior and 50 points for the student's explanatory paper about the house and its owner with quotations from the work (See Table 1).

Table 1. Final assessment sheet of the design concept.

\begin{tabular}{|c|c|c|c|c|}
\hline & D Level & C Level & B Level & A Level \\
\hline 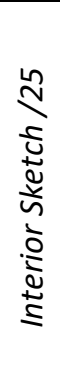 & $\begin{array}{l}\text { The sketch is barely adequate. It } \\
\text { is messy and unfinished, does } \\
\text { not seem to relate to the } \\
\text { character much at all (15-17). }\end{array}$ & $\begin{array}{l}\text { The sketch is } \\
\text { somewhat messy } \\
\text { and not very } \\
\text { detailed. There are } \\
\text { not many elements } \\
\text { revealing an } \\
\text { understanding of the } \\
\text { literary character } \\
(18-19)\end{array}$ & $\begin{array}{l}\text { The sketch is somewhat } \\
\text { detailed, and contains } \\
\text { many elements related } \\
\text { to the literary character } \\
(20-22)\end{array}$ & $\begin{array}{l}\text { The sketch is detailed } \\
\text { and precise, filled } \\
\text { with elements } \\
\text { related to the literary } \\
\text { character }(23-25)\end{array}$ \\
\hline
\end{tabular}




\begin{tabular}{|c|c|c|c|}
\hline $\begin{array}{l}\text { The sketch is barely adequate. It } \\
\text { is messy and unfinished, does } \\
\text { not seem to relate to the } \\
\text { character much at all (15-17). }\end{array}$ & $\begin{array}{l}\text { The sketch is } \\
\text { somewhat messy } \\
\text { and not very } \\
\text { detailed. There are } \\
\text { not many elements } \\
\text { revealing an } \\
\text { understanding of the } \\
\text { literary character } \\
(18-19)\end{array}$ & $\begin{array}{l}\text { The sketch is somewhat } \\
\text { detailed, and contains } \\
\text { many elements related } \\
\text { to the literary character } \\
(20-22)\end{array}$ & $\begin{array}{l}\text { The sketch is detailed } \\
\text { and precise, filled } \\
\text { with elements } \\
\text { related to the literary } \\
\text { character (23-25) }\end{array}$ \\
\hline $\begin{array}{l}\text { The paper has many grammatical } \\
\text { and structural issues. It does not } \\
\text { demonstrate an understanding } \\
\text { of the character or explain the } \\
\text { project choices (30-34). }\end{array}$ & $\begin{array}{l}\text { The paper may have } \\
\text { many grammatical } \\
\text { and structural issues. } \\
\text { It does not make } \\
\text { clear the connections } \\
\text { between the } \\
\text { character and the } \\
\text { project choices, and } \\
\text { may not use text } \\
\text { adequately (35-39). }\end{array}$ & $\begin{array}{l}\text { The paper is strong in } \\
\text { its grammar and } \\
\text { structure. It reveals a } \\
\text { good grasp of the } \\
\text { character and explains } \\
\text { the project choices } \\
\text { through some textual } \\
\text { analysis (40-44). }\end{array}$ & $\begin{array}{l}\text { The paper is nearly } \\
\text { flawless in its } \\
\text { grammar and } \\
\text { structure. It reveals a } \\
\text { deep understanding } \\
\text { of the character and } \\
\text { explains the choices } \\
\text { made through clear } \\
\text { textual analysis (45- } \\
\text { 50). }\end{array}$ \\
\hline
\end{tabular}

The next lesson presented on the teacher's website as a lesson using STEAM technologies is called "The Literary Food Truck Project" (n.d.). The teacher lists English, Literature, and Close Reading as the disciplinary areas for this lesson for grades 9-12. However, based on the plan of the lesson, its literary part seems not the main, but contextual, although it is based on the students' existing literary background. One should note that in this case, we do not perceive the context as an insufficiency: it is a subject for thought. The students' design skills dominate the lesson. Let us consider a lesson plan with a somewhat puzzling start: "Food trucks are everywhere these days. A food truck gives a chef a chance to show a lot of personality" (The Literary Food Truck Project, n.d.). Within the framework of this literary project, as the teacher emphasizes, students must present their food truck in two options:

Option No.1: A Character's Truck. For this option, students will imagine that one character from the current text has decided to leave everything behind and take a food truck out on the road. Students will design the truck from the character's perspective, making appearance, theme, staffing and menu choices based on all the students have learned about the character in the text.

Option No.2: A Truck Themed to the Text. Students will imagine that their truck will be at the world literary conference: famous authors, publishers, journalists, English teachers and students. The students need to make the truck represent the text in every possible way. The students will make choices of appearance, theme and menu based carefully on elements from the text.

There is another lesson for grades 9-10 in the framework of STEAM, where the teacher indicates the language, literature and written language of students as subject dominants. The topic is "Represent Key Scenes in To Kill a Mockingbird with Building Blocks" (n.d.). The task is to present one of the key scenes of the novel as a building made of "blocks" (shoeboxes) reflecting the sequence and logic of events in a fragment of the novel. First, the students are asked to make a content diagram of the selected fragment; the number of points in the diagram should be equal to the number of "blocks" of the building. A diagram and a small text should be attached to the back of the "building" (a retelling of a scene from the novel). Each "brick" from the "facade" must be signed according to the diagram (this can be a short excerpt from the text, and thoughts formulated by the students themselves). The design of the side parts of the "building" is made at the discretion of the student. The finished projects are presented to the class, where its design and student text are discussed. The project is assessed based on the degree to which the "bricks" reflect the main events of the scene; for the design of the entire "building"; the diagram; text describing the main events of the scene and the oral presentation of the project. As the teacher notes in the lesson plan, 
"This art project supports STEAM in the areas of art design and engineering" (Represent Key Scenes in To Kill a Mockingbird with Building Blocks, n.d.).

\section{RESULTS}

After studying a large number of studies concerning the multidisciplinary approach to studying a literary text, one can say with confidence: such a task is not an exotic pedagogical search, it is a manifestation of a comprehensive educational direction.

Today, the school is sufficiently equipped with "reinforcement ribs" of subject methodologies. However, to present to students the cultural and ideological basis of society, broader methodological grounds are needed than the framework of a separate subject. In the future, an integral metamethodological model of humanitarian education should be built (Getmanskaya, 2009, p. 69-70).

Among modern models of general education innovative construction, of particular interest is the concept of culture-creative school, with which we associate STEAM approaches. For the widespread introduction of this concept into educational practice, a coordinated purposeful restructuring of special teaching methods is necessary based on their metamethodological dialogue. Such a dialogue will provide unity in understanding the goals of general education and the way to achieve them in a holistic educational environment. Thus, we can say that metamethodology is not a new discipline that in some way replaces didactics but a dialogue of subject methods aimed to identify and productively use the grounds for integration. In this context, STEAM education is based on a metamethodological approach, in which integration consists in considering the content specificity and developmental potential of specific academic subjects in the direction from the particular to the general.

Along with the understanding of the need to move from a mono-subject approach to teaching at school to a metasubject approach, there are also paradoxical assessments of STEAM education. One of these judgments belongs to a prominent Western scientist, Harvard University professor Dr. Howard Gardner, author of the theory of multiple intelligences. When asked if Dr. Gardner had any ideas on how to incorporate art into STEM education, the scholar replied, "I don't have strong views about whether arts should become a part of STEM or be self-standing. What is important is that every human being deserves to learn about the arts and humanities, just as each person should be cognizant of the sciences" (Jolly, 2014). Today, the metamethodological model is used not only within the walls of Western universities: the approach is even more actively being introduced into the school, including all grades in the process, from the first to graduating (Taylor, 2016; Vizcarra, 2014; Yakman, 2008; Piro, 2010). This refers to an interdisciplinary STEAM approach, in which five disciplines are integrated into a single training scheme: Natural Sciences (S), Technology $(T)$, Engineering $(E)$, Arts $(A)$ and Mathematics $(M)$. Initially, the abbreviation did not contain the letter "A" - Arts. The STEM theory appeared in world pedagogy at the beginning of the $21^{\text {st }}$ century, and only about ten years later the letter " $A$ " was added to STEM.

\section{DISCUSSION}

The transformation of STEM into STEAM faced a mixed reaction in the teaching community: articles appeared where STEM and STEAM approaches were somehow opposed or even compete with each other (Robelen, 2011; Catchen, 2013; Feldman, 2015; Jolly, 2014). What is STEAM education: an approach, a model, a system or a technology? The term's creator and the worldfamous STEAM education consultant G. Yakman (2008) characterizes STEAM as an educational model; A. Feldman (2015) - as practice-oriented projects; E. Robelen (2011) actualizes in STEAM the 
possibilities of unlocking the creative thinking of students; R. Catchen (2013) emphasizes that in STEAM, students begin to learn things about themselves they did not know.

The key material for the STEAM theory is the article "STEM vs. STEAM: Do the Arts Belong?" by A. Jolly (2014). The main questions posed by the author in his work are: how to introduce Art into STEAM education organically; is it possible to combine Art with only one of the main subjects, for example, Natural Science and ignore such significant subjects as Mathematics and Engineering? A. Jolly proposes to form curricula where Art is viewed as an applied subject, the same as Mathematics and Natural Sciences. The applied nature of Art in the classroom, in A. Jolly's logic, is realized through Design and Performing Arts. Students apply decoration and design skills to the products (works) that are created in the classroom. The students use computer graphics to design logos for reports and presentations; using industrial design, students improve the appearance and functionality of a product created during an inventive (engineering) project. Performing Arts (dramatization and expressive reading) as well as writing technical text and reasoned written utterance, according to A. Jolly's theory, naturally fit into communication in the process of invention. At the same time, the researcher cautions: Art is often advertised as a means of creativity in STEM projects, but engineers, as a rule, lack creativity. The goal of STEAM, according to the scholar, "should not be so much to teach art but to apply art in real situations" (Jolly, 2014).

In the article "Reflections: How STEM becomes STEAM" by R. Catchen (2013) as in A. Jolly's work, the most important skill for working in the framework of STEAM technologies is the communication skill: "You can have the greatest idea, but no one will know if you can't clearly communicate it". The scholar recommends ending each lesson with the students' written reflection on the teacher's questions, since the students' writing skills, especially in descriptive and essay texts, are poor. The subject of description in these works can be the design of architectural ensembles, a fragment of a painting, the formula of the golden ratio in Leonardo da Vinci's paintings, a trip to Mars, space exploration, a comic strip about the Martians. At the same time, R. Catchen admits that the introduction of STEAM technologies is slow. During R. Catchen's practical search for the implementation of STEAM technologies, the scholar often heard such feedback from teachers: "great ideas, but we need to focus on core curriculum and raise student achievement in writing, reading, math and science" (Catchen, 2013). Naturally, despite all the interest in STEAM ideas, it is not easy for a teacher to find a place for them in the traditional educational process.

If we talk about specific definitions of STEAM education, then in Russian publications, for example, they are generalized; they emphasize mainly the presence of interdisciplinary technologies. For example, in the work by T.V. Vojtova (2018), STEAM education is based on the use of an interdisciplinary and applied approach, as well as the integration of all five disciplines into a single teaching scheme. Western definitions are more essayistic and, at the same time, do not always reflect the innovative essence of STEAM education. Thus, in the work by P.Ch. Taylor (2016) "Why is a STEAM curriculum perspective crucial to the 21st century?" the goal of STEAM education is "to prepare children with '21st century skills' for the jobs of the future, including the ability 'to think smart and creatively, solve problems, persist and take risks, have strong digital skills and know how to collaborate effectively'" (p. 89).

Let us turn to the topics of the latest Russian scientific conferences and forums dedicated to STEAM education. Two years ago in Moscow, the Expocenter hosted the International Forum "Technologies in Education. STEM vs STEAM"(March 28, 2019). At the Moscow City Pedagogical University, a conference was organized "STEM-career and innovative business: What a modern teacher needs to know about it" (November 15, 2019). At the Kaliningrad University named after I. Kant, the conference "STEAM Practices in Education" was held (April 13, 2019). What characteristic topics were raised at these conferences? At the Forum at the Expocenter, which is a demonstration platform for innovative technologies, ideas, and concepts, new school equipment was presented. At the Kaliningrad University, the advantages of general developmental programs that integrate the 
content of various subject areas were analyzed. At the Moscow State Pedagogical University, they focused on increasing the attractiveness of high-tech professions in the teaching community to further improve the quality of the natural science and engineering training of schoolchildren. Thus, the main topics of these scientific events were the quality of teacher training in the context of STEAM education, the quality of STEAM programs, and the necessary equipment that provides the STEAM product of the lesson.

Another interpretation of the STEAM approach in education was indirectly reflected in the concept of the Russian scientist-economist A.A. Auzan. In A. Arkhangelsky's TV show "In the meantime. Meanings. Is economics the humanities?" (December 10, 2019), the participants discussed the fact that mathematicians and economists should be taught various arts (liberal arts). For example, they should be offered a special course on drama by W. Shakespeare. As evidence of the expediency of this, Auzan cited the following metaphor. For millennia, foxes have been catching hares, but they just cannot exterminate them, even though foxes are stronger and smarter than hares. Why? Because the fox does not know how the hare will run from her. However, the hare itself does not know how it will run from the fox. Today, from Auzan's point of view, begins an era of rivalry between human and artificial intelligence, albeit still weak. Proceeding from this, current university graduates should have such emotional intelligence and thinking skills (including the rightbrain ones) that the hardest to algorythmisize and cannot be programmed by artificial intelligence (Telekanal "Kul'tura", 2019). It seems to us that Auzan's thought accurately describes the goalsetting and the expediency of using STEAM technologies in modern education.

Materials about STEAM education began to appear in pedagogical periodicals back in 20052006. However, even though more than 15 years have passed, not a single monograph has appeared that would systematically cover these technologies. From our point of view, this is due to the fact that STEAM education is, first of all, a practice-oriented system, where the main and, perhaps, the only theoretical position is the following. A student who is familiar with the artistic foundations of life (literature, painting, music, artistic design) achieves more in mathematics, invention, and natural sciences. In our opinion, this cannot be questioned but requires years of experimental research.

\section{CONCLUSION}

STEAM programs are becoming more and more visible in the West, due to this, part of the scientific community believes that the addition of the "art" component distracts the students from the exact sciences and the change from STEM to STEAM technology only exacerbates this problem (Catchen, 2013). However, we think that the STEAM movement is not aimed at reducing the time spent on studying Science, Technology, Engineering and Mathematics to make room for the Arts. The approach is about sparking the imaginations of both humanities-oriented and tech-minded students alike. STEAM uses art as a shortcut to science for undecided students. With the introduction of STEAM technologies, the "pressure" on the student is reduced, the strict obligation of the student's future only as a scientist or engineer is removed. The student can be a designer, digital artist, programmer, art director, scientist and engineer at the same time. STEAM eliminates the long-standing dispute between "physicists" and "lyricists" because within its framework, a lyricist can become talented in engineering (invention), and a physicist can be talented in aesthetic, artistic manifestations, for example, in design.

Then what about literary education: does it lose or gain in the framework of STEAM technologies? Does the study of a literary text dissolve in visual arts and design, drifting into a general humanitarian context? The challenge for practicing teachers is to use the STEAM approach as a means of developing, not reducing literary education. STEAM technologies are a big step forward in modern pedagogy, at the same time their implementation is a serious challenge to preserve traditional approaches to the study of a literary text and formulate new impulses for its development in a new reality. 
Authors' Contributions: Elena Getmanskaya: conception and design, acquisition of data, analysis and interpretation of data, drafting the article, critical review of important intellectual content. The author had read and approved the final version of the manuscript.

Ethics Approval: Not applicable.

Acknowledgments: Not applicable.

\section{REFERENCES}

Anzaldo, A., Boeck, C., \& Schupack, S. (2017). Literary digest: cannibal poetry and biology. The STEAM Journal, 3(1), Art. 20. https://doi.org/10.5642/steam.20170301.20

Catchen, R. (2013). Reflections: how STEM becomes STEAM. The STEAM Journal, 1(1), Art. 22.

https://doi.org/10.5642/steam.201301.22

Department for Education. (April 9, 2014). GCE AS and A level subject content for English

literature. GOV.UK. Available: https://www.gov.uk/government/publications/gce-as-and-a-level-for-english-literature

Feldman, A. (June 16, 2015). STEAM rising: why we need to put the arts into STEM education. SlateGroup. Available: https://slate.com/technology/2015/06/steam-vs-stem-why-we-need-to-put-the-arts-into-stem-education.html) (date of access: April 26, 2021).

Getmanskaya, E. V. (2009). Dvoinaya funktsiya ehvristicheskogo metoda obucheniya. Izvestiya Volgogradskogo gosudarstvennogo pedagogicheskogo universiteta, 9(43), 69-73 (in Russ.).

Institute for Arts Integration and STEAM. (n.d.). Available: https://artsintegration.com

Jolly, A. (November 18, 2014). STEM vs. STEAM: do the arts belong? EducationWeek. Available:

https://www.edweek.org/tm/articles/2014/11/18/ctq-jolly-stem-vs-steam.html (date of access: April 26, 2021).

The Literary Food Truck Project. (n.d.). Available: https://www.teacherspayteachers.com/Product/The-Literary-FoodTruck-Digital-and-PDF-2066452?st=53534b26d33aad70218cc83717c809e7

MelisBuzzFeed. (February 8, 2011). 50 Stunning Homes Built Into Nature. BuzzFeed. Available: https://www.buzzfeed.com/melismashable/50-stunning-homes-built-into-nature

Piro, J. (March 9, 2010). Going fron STEM to STEAM. EducationWeek. Available: https://www.edweek.org/ew/articles/2010/03/10/24piro.h29.html (date of access: April 26, 2021).

Represent Key Scenes in To Kill a Mockingbird with Building Blocks. (n.d.). Available:

https://www.teacherspayteachers.com/Product/Represent-Key-Scenes-in-To-Kill-a-Mockingbird-with-Building-Blocks3645983?st=6a93af4bff1c141a9b5f8071dfc5bf90

Robelen, E.W. (December 1, 2011). STEAM: experts make case for adding arts to STEM. EducationWeek. Available: https://www.edweek.org/ew/articles/2011/12/01/13steam_ep.h31.html (date of access: April 26, 2021).

STEM ELA Activity: literary character designs a home. (n.d.). Available:

https://www.teacherspayteachers.com/Product/STEM-ELA-Activity-Literary-Character-designs-a-Home-

2053988?st=85c75964d9349b6a910d1bf9a1e650a1

Steptoe, J. (1987). Mufaro's beautiful daughters: an African tale (Picture Puffin). Scholastic, 32 p.

Taylor, P. C. (2016). Why is a STEAM curriculum perspective crucial to the 21st century? In: ACER Research Conference 2016, Improving STEM learning: what will it take? Brisbane, Australia, pp. 89-93.

Telekanal "Kul'tura”. (December 10, 2019). A. Arhangel'skij “Tem vremenem. Smysly. Ekonomika - gumanitarnaya nauka?”. Available: ttps://tvkultura.ru/video/show/brand_id/63152/episode_id/2224927/video_id/2251455/

Temple, E. (August 5, 2012). 10 Amazing Recycled Houses. Flavorwire. Available: http://flavorwire.com/315520/10amazing-recycled-houses

Vizcarra, D. (2014). STEAM inspired by insight. The STEAM Journal, 1(2), Art. 26.

https://doi.org/10.5642/steam.20140102.26

Vojtova, T. V. (2018). Chto takoe STEAM-obrazovanie? Vestnik nauchnyh konferencij, 12-3(40), $36-37$ (in Russ.).

Willett-Wei, M. (June 20, 2013). The 18 most interesting homes on the planet. Insider. Available:

http://www.businessinsider.com/the-18-coolest-homes-on-earth-2013-6 
Yakman, G. (2008). STEAM Education: an overview of creating a model of integrative education. Available: https://www.researchgate.net/publication/327351326 STEAM Education an overview of creating a model of int egrative education (date of access: April 26, 2021).

Received: 03 August 2021 | Accepted: 12 September 2021 | Published: 11 October 2021 distribution, and reproduction in any medium, provided the original work is properly cited. 